\title{
The Mediterranean Sea system: a review and an introduction to the special issue
}

\author{
T. Tanhua ${ }^{1}$, D. Hainbucher ${ }^{2}$, K. Schroeder ${ }^{3}$, V. Cardin ${ }^{4}$, M. Álvarez ${ }^{5}$, and G. Civitarese ${ }^{4}$ \\ ${ }^{1}$ GEOMAR Helmholtz Centre for Ocean Research Kiel, Department of Chemical Oceanography, Düsternbrooker Weg 20, \\ 24105 Kiel, Germany \\ ${ }^{2}$ ZMAW, Institut für Meereskunde, University of Hamburg, Bundesstraße 53, 20146 Hamburg, Germany \\ ${ }^{3}$ CNR - ISMAR, Institute for Marine Science, Arsenale - Tesa 104 Castello 2737/F, 30122 Venezia, Italy \\ ${ }^{4}$ OGS - Istituto Nazionale di Oceanografia e di Geofisica Sperimentale, Borgo Grotta Gigante 42/c, \\ 34018 Sgonico (Trieste), Italy \\ ${ }^{5}$ IEO, Instituto Español de Oceanografía, Centro de A Coruña, Apdo. 130, 15001 A Coruña, Spain
}

Correspondence to: T. Tanhua (ttanhua@geomar.de)

Received: 11 March 2013 - Published in Ocean Sci. Discuss.: 21 March 2013

Revised: 8 June 2013 - Accepted: 3 August 2013 - Published: 6 September 2013

\begin{abstract}
The Mediterranean Sea is a semi-enclosed sea characterized by high salinities, temperatures and densities. The net evaporation exceeds the precipitation, driving an anti-estuarine circulation through the Strait of Gibraltar, contributing to very low nutrient concentrations. The Mediterranean Sea has an active overturning circulation, one shallow cell that communicates directly with the Atlantic Ocean, and two deep overturning cells, one in each of the two main basins. It is surrounded by populated areas and is thus sensitive to anthropogenic forcing. Several dramatic changes in the oceanographic and biogeochemical conditions have been observed during the past several decades, emphasizing the need to better monitor and understand the changing conditions and their drivers. During 2011 three oceanographic cruises were conducted in a coordinated fashion in order to produce baseline data of important physical and biogeochemical parameters that can be compared to historic data and be used as reference for future observational campaigns. In this article we provide information on the Mediterranean Sea oceanographic situation, and present a short review that will serve as background information for the special issue in Ocean Science on "Physical, chemical and biological oceanography of the Mediterranean Sea". An important contribution of this article is the set of figures showing the large-scale distributions of physical and chemical properties along the full length of the Mediterranean Sea.
\end{abstract}

\section{Introduction}

The Mediterranean Sea is a landlocked sea with limited exchange with the world ocean, an active deep overturning circulation, a shallow circulation cell and a complex upper layer circulation with several permanent and quasipermanent eddies. The Mediterranean Sea exports intermediate depth water to the Atlantic Ocean and thereby directly, and significantly, influences the oceanographic conditions there. Also, due to the limited exchange of properties with the world ocean and the internal transformation processes, it has been suggested that it can be considered a "laboratory" of a "mini-ocean", representing processes that take place at a larger scale in the world ocean (e.g. Robinson and Golnaraghi, 1994; Bergamasco and Malanotte-Rizzoli, 2010) . The Mediterranean Sea is not in steady state with sporadic deep water formation events and is potentially sensitive to climatic changes. Much remains to be known with regard to the biogeochemistry, the dynamics of the circulation and ventilation of the Mediterranean system, the connection between circulation, biogeochemistry and biological activity, and the possible implications for climate relevant feedback mechanisms. Monitoring and modeling the evolution of the dynamics of the Mediterranean Sea and the impact on biogeochemistry is an essential part of its observational system. This seems particularly relevant in light of the significant changes that have been observed during recent decades (e.g. 
Roether et al., 1996; Tsimplis et al., 2006; Schroeder et al., 2012.)

This article provides a brief review of the physical and chemical oceanography in the Mediterranean Sea as background information and introduction to the special issue in Ocean Science on "Physical, Chemical and Biological Oceanography of the Mediterranean Sea". We start by introducing three almost synoptic cruises conducted during 2011 that covered all major basins of the Mediterranean Sea, from its eastern extreme through the Strait of Gibraltar. The largescale data collected during these three cruises will be presented in the form of sections, so that the properties and the biogeochemistry of the Mediterranean system can be discussed in this context. Since the Meteor cruise M84/3 crossed the length of the Mediterranean Sea from off the coast of Lebanon to the Strait of Gibraltar, it is possible to draw a quasi-zonal section. However, there is a data gap in the Sicily Channel since we were not able to survey that area due to political instability. Additionally, we present a short meridional section from the Adriatic Sea through the Strait of Otranto to the Ionian Sea. All panels are split into a shallow and a deep part in order to enhance the upper water column where larger gradients are encountered. The objective of presenting these sections is to describe the large-scale distribution of properties in the Mediterranean Sea, which will be discussed in more detail in several other papers of the special issue.

The special issue contains contributions on various aspects of chemical, physical and biological oceanography of the Mediterranean Sea. The idea of a special issue was born among the authors of this article after three cruises were executed in 2011; these were performed in a coordinated fashion with the aim of acquiring data for a (nearly) synoptic picture of distribution of chemical, physical and biological properties across the major parts of the Mediterranean Sea, including all major sub-basins. We further intended to use these physical and chemical data to determine changes in circulation and ventilation and to quantify changes in inventory and distribution of properties.

Particularly large gaps in our understanding of the Mediterranean Sea exist with regard to the carbonate system and the uptake of anthropogenic carbon; this is addressed in an article by Álvarez et al. (2013) using data from two synoptic cruises in 2011. Another important theme in the Mediterranean is the strength of the deep water formation, and the temporal and spatial variability. Since a suite of several, independent, transient tracers were measured during 2011 the ventilation of the Mediterranean Sea can be constrained. The Mediterranean ventilation is addressed in three articles in this special issue; Roether et al. (2013a) discuss the distribution of tritium and the decay product ${ }^{3} \mathrm{He}$ from the M84/3 cruise as well as historic measurements. Similarly, Schneider et al. (2013) discuss temporary variations in Mediterranean ventilation based on M84/3 data and the historic archive of transient tracers. Stöven and Tanhua's (forth- coming) "Ventilation of the Mediterranean Sea constrained by multiple transient tracer measurements, manuscript in preparation" constrains the contemporary ventilation based on the transient tracer data from the M84/3 cruise, using the transit time distribution framework. With regard to the biological oceanography of the Mediterranean Sea, Mapelli et al. (2013a, b); Mapelli et al. (2013b) reports on results from an innovative molecular microbiological investigation across horizontal and vertical gradients in the Mediterranean. Also, results from nitrogen fixation incubations performed during M84/3 are reported by Rahav et al. (2013) that find higher rates of $\mathrm{N}_{2}$ fixation close to the Strait of Gibraltar, and lower rates in the eastern Mediterranean. Aspects of the Mediterranean physical oceanography are also discussed in the special issue; for instance, Gačić et al. (2013) correlate decadal salinity variability in the Levantine Basin and in the Levantine Intermediate Water in the Strait of Sicily using historic data. In another article, Kassis et al. (2013) present data from the POSEIDON-Pylos observatory, a multi-platform in the southeastern Ionian Sea, and discussed the dynamics of the Ionian Sea thermocline and variability of the deeper layers.

\section{Observations during 2011}

During spring and early summer of 2011, three cruises in the Mediterranean Sea were conducted in a coordinated way: The German R/V Meteor (cruise M84/3, Istanbul to Vigo, 528 April 2011), the German R/V Poseidon (cruise POS414, Genoa to Messina, 31 May to 13 June 2011) and the Italian R/V Urania (cruise EF11, Bari to La Spezia, 22 April to 8 May 2011). The CTD-station network for the three cruises is shown in Fig. 1. Even though the goals of the three campaigns had slightly different focus and scopes, it allowed for a synoptic view of property and parameter distribution across large parts of the Mediterranean Sea, including all major subbasins. Thus, the combined data set can be used to estimate changes in circulation and ventilation, and, in addition, temporal and spatial change as well as variations in the distribution and inventory of properties (such as inorganic carbon, i.e. uptake of anthropogenic carbon) can be quantified. A short description of each cruise will be given below. The three cruises had a few overlapping stations (see Fig. 1) that were useful for internal consistency checks and calibration of measured properties between the campaigns. Due to political unrest, none of the three cruises were able to conduct any sampling in the Sicily Channel; there is thus a gap in the 2011 data coverage for this area that connects the eastern and western basins.

The Meteor cruise M84/3 was set up to follow the demands and requirements of repeat hydrography cruises as specified by the GO-SHIP group (http://www.go-ship.org/), i.e. with a comprehensive set of physical and chemical parameters measured to the highest standards. These ideas are also echoed in a recent initiative to design a repeat 


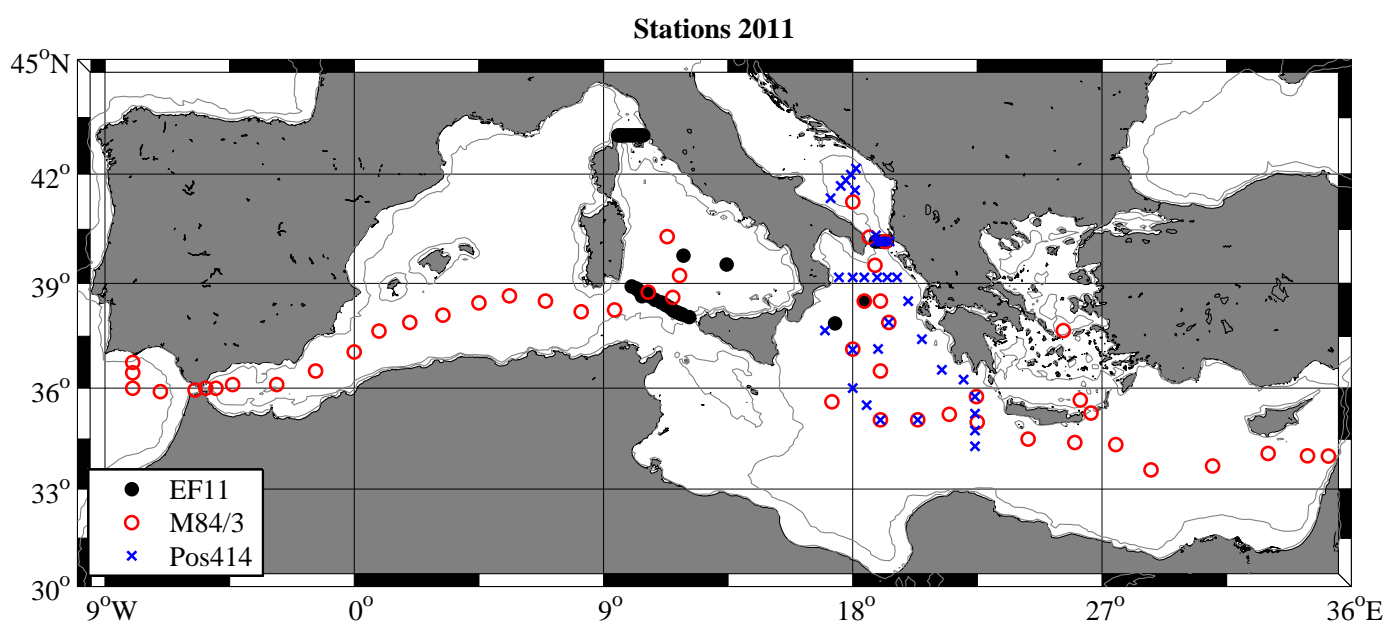

Fig. 1. Map of the Mediterranean Sea with the positions of the three quasi-synoptic cruises marked, see text. The $500 \mathrm{~m}$ isobaths are marked with a thin gray line.

hydrography program for the Mediterranean Sea (CIESM, 2012). The goal of the M84/3 cruise was to follow the track of previous cruises through the eastern and western Mediterranean, some of which with extensive chemistry and tracer observational components. The principal scientific objectives for M84/3 had two closely linked components: (1) understanding and documenting the large-scale water property distributions, their changes and the drivers of those changes, and (2) addressing questions for a future Mediterranean Sea higher in dissolved inorganic carbon, more stratified, which has experienced changes in circulation and ventilation related to climate change. A close related goal was to fill in gaps in the knowledge of the carbonate system of the Mediterranean Sea, including its sub-basins, e.g. to improve estimates of the anthropogenic carbon content and to document the temporal trend in dissolved inorganic carbon. More details about the cruise can be found in Tanhua et al. (2013).

The primarily goal of the cruise on the R/V Poseidon (POS414) was to identify and quantify the routes and entrainment rates of the Adriatic Deep Water into the Ionian Sea and to investigate the spatial and temporal variability of the spreading and mixing of the Eastern Mediterranean Deep Water. The cruise was a continuation of the work carried out during previous cruises in the area aimed at investigating the processes of deep water formation, the origin of the deep water in the eastern Mediterranean and possible switches of those sources. During the cruise 33 full-depth CTD stations were carried out and at all stations samples for nutrients and oxygen were taken at 12 depth levels, and samples for oxygen isotopes were taken at 6 depth levels. Continuous measurements were made with the vessel-mounted ADCP and thermosalinograph; see Hainbucher (2012) for more information.

The general objective of the cruise on the R/V URANIA (EF11) was the development of a dynamic calibration pro- cedure for oceanographic sensors, the continuation of the long-term monitoring of straits, and the investigation of the oceanographic conditions in areas important for inter-basin exchanges and deep water dynamics, such as the Corsica and Sicily Channels and the Tyrrhenian Sea. The EF11 survey was planned to cover the Sicily Channel in greater detail, but unfortunately the geopolitical situation in 2011 in this region prevented us from completing the planned ship track; also rough weather conditions impacted the cruise-track. Nevertheless, two inter-calibration stations were maintained in order to compare the physical and chemical data at the same stations with those collected by the other two ships. Along with the classical physical measurements (CTD, LADCP, $\mathrm{ADCP}$ ), samples for dissolved inorganic nutrients, $\mathrm{pH}$, total alkalinity, total organic carbon and dissolved inorganic carbon were collected.

\section{Hydrography of the Mediterranean Sea}

A comprehensive review of the Mediterranean oceanography is provided by Nielsen (1912) in a classic work that sums up the knowledge at the beginning of the 20th century. Almost 50 yr later Wüst (1961) presents property distributions (salinity, temperature and oxygen) of the Mediterranean Sea system, and discusses the vertical circulation for both the shallow overturning cell involving the Levantine Intermediate Water (LIW) and the deep water formation in both basins. Several more recent works are reviewing water mass formation, circulation and mixing within the Mediterranean System (e.g. Robinson et al., 2001; Millot and Taupier-Letage, 2005; Bergamasco and Malanotte-Rizzoli, 2010; Schroeder et al., 2012). Additionally, Tsimplis et al. (2006) reviews recent changes in the oceanography attributed to climate variability. The Mediterranean Sea is clearly a dynamic system with significant temporal and spatial variability and where 


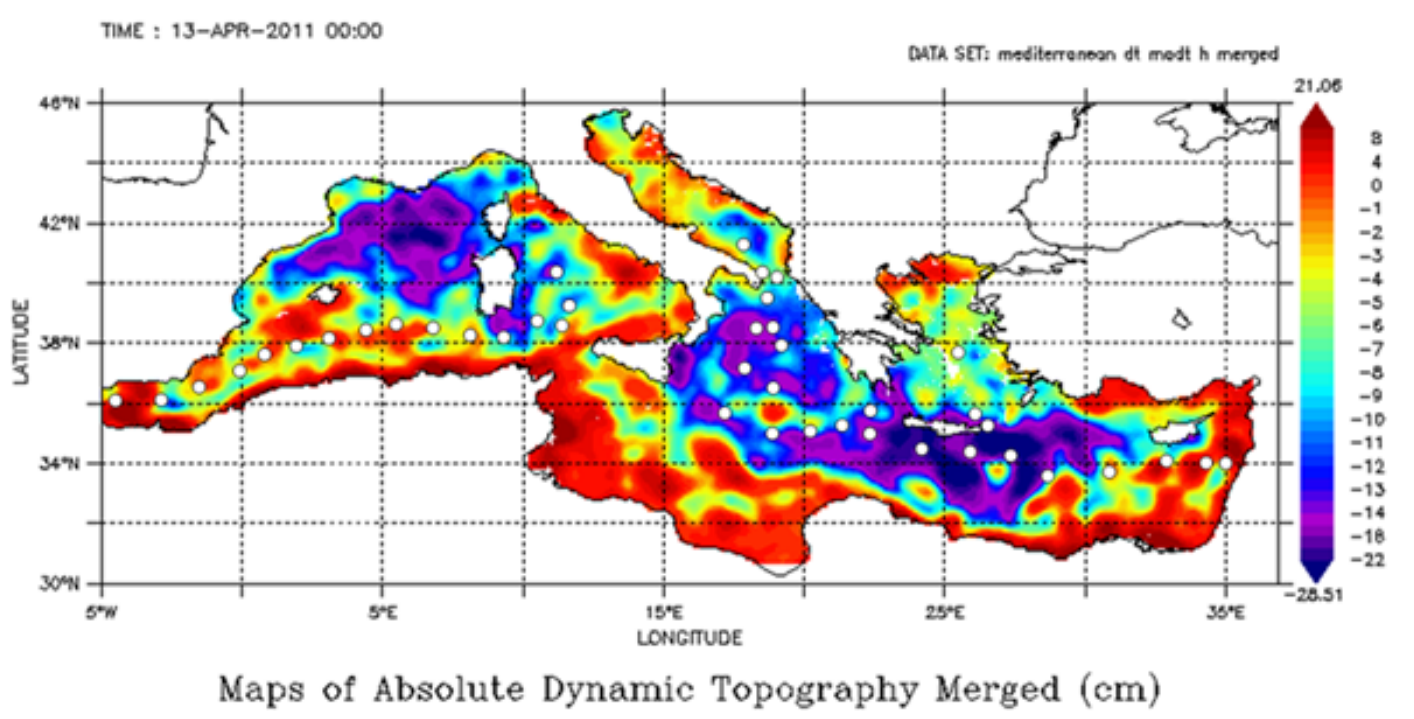

Fig. 2. Absolute Dynamic Topography (ADT) map of the Mediterranean averaged over the second half of April 2011.

several permanent structures interact with gyres and eddies (both permanent and intermittent). This can be exemplified with a map of the absolute dynamic topography (ADT) of the Mediterranean Sea averaged over the second half of April 2011, i.e. about the time period of the M84/3 and EF11 cruises (Fig. 2). This map shows some features that are of interest for the interpretation of the data from these cruises. For instance the low ADT in the Ionian Sea that suggests a cyclonic circulation regime, which can be correlated to salinity and nutrient concentrations in the Adriatic Sea (e.g. Civitarese et al., 2010).

\subsection{Hydrology of the Mediterranean Sea}

The Mediterranean Sea is an evaporation basin, i.e. the mean evaporation exceeds precipitation, which has important implications for the circulation and the biogeochemistry of the sea. The dominating term in the water balance of the Mediterranean Sea is the exchange with the North Atlantic Ocean through the Strait of Gibraltar. The inflow of Atlantic Water (AW) has been estimated to be $0.72-0.92 \mathrm{~Sv}$ (Sverdrup, $10^{6} \mathrm{~m}^{3} \mathrm{~s}^{-1}$ ) and the outflow of Mediterranean Overflow Water (MOW) to be $0.68-0.88 \mathrm{~Sv}$ using combinations of observations (primarily of the MOW), models, and evaporation/precipitation data to balance the hydrological budget with the inflowing Atlantic Water (e.g. Bryden and Kinder, 1991; Bryden et al., 1994; Tsimplis and Bryden, 2000; Baschek et al., 2001; García-Lafuente et al., 2011). The Mediterranean Sea also exchanges water with the Black Sea through the Turkish Strait System, i.e. the Dardanelles, the Marmara Sea and the Bosphorus Strait. This flow shows large temporal variability partly associated with variability in the river runoff to the Black Sea, and is also influenced on shorter timescales by atmospheric variability. In a review by Ünlüata et al. (1990), the upper layer flow from the Black Sea to the Mediterranean Sea is estimated to be $0.039 \mathrm{~Sv}$ whereas the lower layer flow towards the Black Sea is $0.030 \mathrm{~Sv}$. This is very close to the annual averages that are presented by Kanarska and Maderich (2008) based on model calculations. The flows, in both directions, at the Bosphorus exit to the Black Sea are significantly lower, a result of significant recirculation and vertical mixing in the strait system. Although the inflow from the Black Sea to the Mediterranean Sea is small in comparison to the inflow of the AW through the Strait of Gibraltar, it is still significant, in particular due to the low salinity of the Black Sea inflow water.

The Mediterranean Sea also receives significant amounts of freshwater from river discharge. Although various estimates of the river input is found in the literature, a study by Struglia et al. (2004) found the total mean river discharge to the Mediterranean to be approximately $0.010 \mathrm{~Sv}$ by compiling monthly discharge time series from a large number of rivers. Significant temporal changes in the river discharge to the Mediterranean is evident; the most significant is the reduced flow from the river Nile due to damming, but also other parts of the Mediterranean are, and have been, experiencing temporal variations. In addition to the riverine discharge to the Mediterranean Sea, an often overlooked source of freshwater is provided by submarine groundwater discharge (SGD). Although the importance of SGD to the Mediterranean Sea is currently poorly constrained, its magnitude is likely similar to the river discharge. SGD is likely an important source of freshwater, nutrients, trace metals, alkalinity etc. to the Mediterranean System (e.g. Moore, 2006a, b), particularly since the Mediterranean Sea 

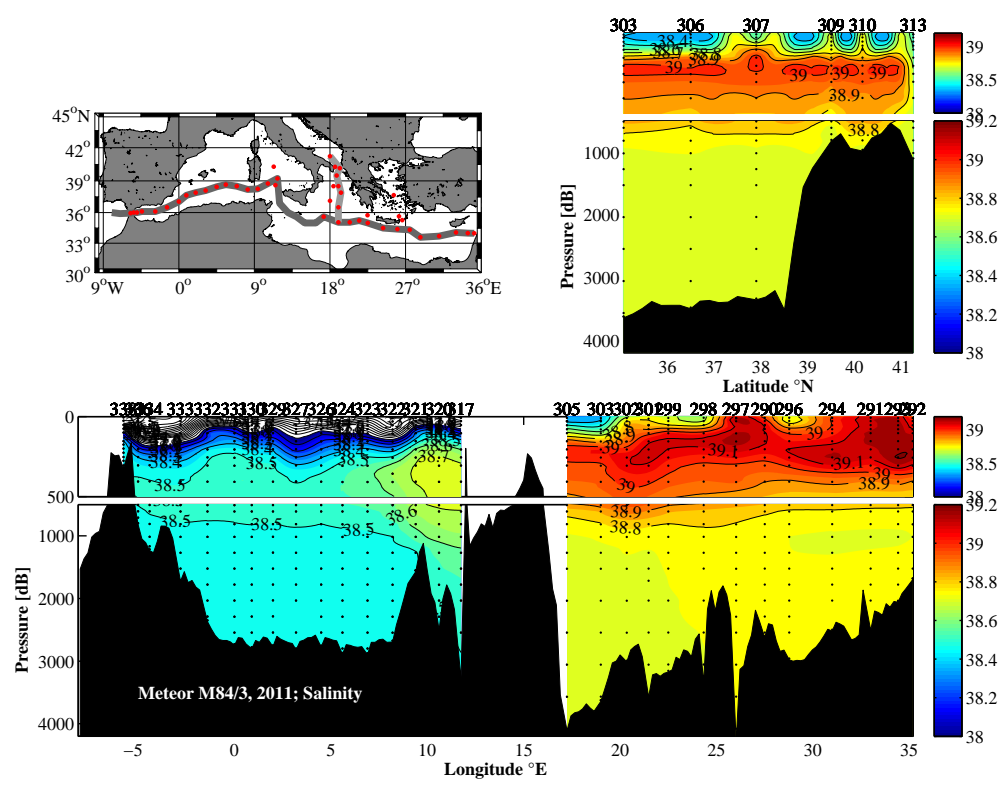

Fig. 3. Sections of salinity in the Mediterranean Sea from the Meteor cruise M84/3 in April of 2011. The top-right panel is a meridional section from the Adriatic Sea to the Ionian Sea (light gray line on the map) and the lower panel is the zonal section from the coast of Lebanon in the eastern Mediterranean Sea to through the Strait of Gibraltar (dark gray line on the map). The depth scale and the color scale are identical for all panels. The top $500 \mathrm{~m}$ in each section are slightly expanded. No stations are shown in the Atlantic due to the very different salinities encountered there as compared to the Mediterranean Sea.

is landlocked. Mariotti et al. (2002) summarizes the hydrological cycle of the Mediterranean Sea and reports on net evaporation and precipitation in the conventional units of $\mathrm{mm} \mathrm{yr}^{-1}$. In order to compare these estimates with other fluxes to the Mediterranean Sea we convert this to units of Sverdrups $\left(10^{6} \mathrm{~m}^{3} \mathrm{~s}^{-1}\right)$, using the area of $2.5 \times 10^{12} \mathrm{~m}^{2}$ for the Mediterranean Sea. The annual mean precipitation is reported to be $0.026-0.037 \mathrm{~Sv}$, whereas the evaporation is $0.074-0.093 \mathrm{~Sv}$, so that the net E-P difference is approximately 0.039-0.055 Sv (Mariotti et al., 2002).

The flow through the Strait of Gibraltar is thus by far the dominant water exchange across the Mediterranean limits. However in terms of freshwater content, precipitation is the dominating source, followed by river and SGD input. The evaporation is the second largest term in the hydrological budget; its effect can be seen in a section of the salinity through the Mediterranean Sea (Fig. 3).

\subsection{The shallow overturning of the Mediterranean Sea}

The surface of the eastern Mediterranean Sea is characterized by high salinity, whereas the relatively low salinity inflow of AW through the Strait of Gibraltar dominates the western Mediterranean Sea. The AW mainly follows a cyclonic circulation of the western Mediterranean (e.g. Millot, 1999; Tsimplis et al., 2006), starting along the North African coast eastwards as the Algerian current. This current generates several short-lived mesoscale and larger open sea eddies that are important for transporting AW to the interior basin (e.g. Fig. 2).
The main part of the AW flows through the Sardinia Channel into the Tyrrhenian Sea, and a smaller portion flows into the eastern Mediterranean Sea through the Sicily Channel. In the Tyrrhenian Sea the AW follows a general cyclonic circulation with several eddies and meanders (e.g. Vetrano et al., 2010). In the northern Tyrrhenian Sea one branch of the AW flows through the Corsica Channel and forms the northern current along the northwestern border, completing the cyclonic circulation in the western basin.

The AW that flows through the Sicily Channel enters the Ionian Sea and the eastern Mediterranean. The principal flow is in a cyclonic circulation, with the Libyo-Egyptian current along the north coast of Africa and several mesoscale anticyclonic eddies forming to the north of the coastal current, some of which are quasi-permanent (e.g. Millot and Gerin, 2010; Gačić et al., 2011), as seen in Fig. 2. However, recently it has been observed that the dominating upper water circulation in the northern Ionian Sea, i.e. the North Ionian Gyre (NIG), shifts between cyclonic and anti-cyclonic on roughly decadal timescales (e.g. Borzelli et al., 2009; Gačić et al., 2011). The main effect of this is that the relatively low salinity water of the AW is either preferable flowing northward around the Ionian Sea or on a more direct route towards the Cretan Passage and the Levantine Basin, see discussion below.

A tongue of high salinity water that stretches westward from the Levantine Basin can clearly be seen in Fig. 3; this is the telltale of the LIW. AW and LIW are the two main components of the shallow circulation cell of the 


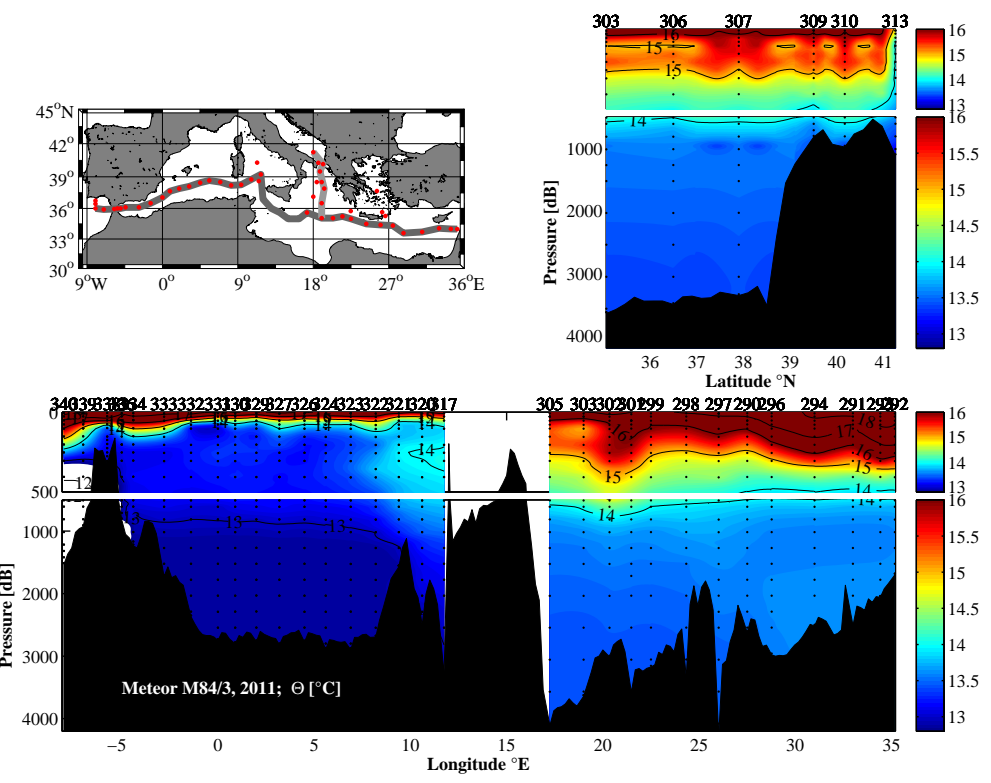

Fig. 4. Similar to Fig. 3, but for potential temperature.

Mediterranean that transforms inflowing AW to LIW in the Eastern Mediterranean Sea (Levantine Sea). The LIW is characterized by a salinity maximum layer at approximately $200-500 \mathrm{~m}$ depth and potential densities of 29.0 $29.1 \mathrm{~kg} \mathrm{~m}^{3}$ (e.g. Wüst, 1961; Malanotte-Rizzoli and Hecht, 1988; Roether et al., 1998). The formation area of LIW is in the area east of Rhodes and possibly in the Cretan Sea (Roether et al., 1998), from where it spreads both to the east, to the Levantine basin, and west, to the Ionian Sea, with a significant flow north towards the Adriatic, where the LIW is an important component in the formation of deep water (e.g. Roether et al., 1998). Transport times of LIW from the formation area to the Sicily Channel have been determined to be $8 \mathrm{yr}$ based on transient tracer data (Roether et al., 1998) or 10-13 yr based on salinity anomalies (Gačić et al., 2013). The transport of LIW through the eastern Mediterranean is also affected by the circulation in the northern Ionian Sea, influencing for instance the conditions in the Adriatic Sea as well. As the LIW passes the Sicily Channel, most of it makes a cyclonic tour around the Tyrrhenian Sea and enters the western Mediterranean Sea through the Sardinia Channel boarding the western coast of Sardinia (Millot, 1999; Vetrano et al., 2010). Due to the high density of the LIW, significant downward mixing is evident within the Tyrrhenian Sea down to about $1800 \mathrm{~m}$ depth (Millot, 1999; Roether and Lupton, 2011). A fraction of the LIW flows out of the Tyrrhenian northwards and enters the Ligurian Sea and the Provençal Basin, becoming the preconditioning agent in the dense water formation in the Gulf of Lions. Most of the LIW finally exits the Mediterranean Sea as MOW through the Strait of Gibraltar as the principal water mass that is exported to the Atlantic Ocean from the Mediterranean Sea.
The MOW exits the Mediterranean Sea below the inflowing AW, i.e. this is a typical anti-estuarine circulation. The outflow of Mediterranean waters into the Atlantic Ocean supports a water layer or high salinity and temperature present over much of the North Atlantic at intermediate depth. The characteristics of the MOW have direct implications for the stability of the North Atlantic Meridional Overturning Circulation, and raises the possibility of feedback mechanisms that, on different timescales, may have direct climatic implications for the region and, potentially, over larger areas (e.g. Ulbrich et al., 2006).

\subsection{The deep overturning of the Mediterranean Sea}

The deep water of the eastern basin is significantly more saline and warmer than the deep water of the western basin (Figs. 3 and 4), and consequently the potential density referenced to surface pressure $\left(\sigma_{\theta}\right)$ is higher in the eastern basin (Fig. 5). These differences are reflections of the different deep water formation regions and the differences in hydrographic pre-conditioning of the water prior to deep water formation.

\subsubsection{Eastern Mediterranean Sea}

The sections in Figs. 3 and 4 clearly demonstrate large differences in salinity and temperature in the deep and intermediate waters between the eastern and western basin. This is related to the separate deep water formation processes taking place in each basin (i.e. in the western and eastern Mediterranean Sea) that transport water from the upper water column to the deep interior. The Adriatic Sea is the principal deep water formation area in the eastern Mediter- 


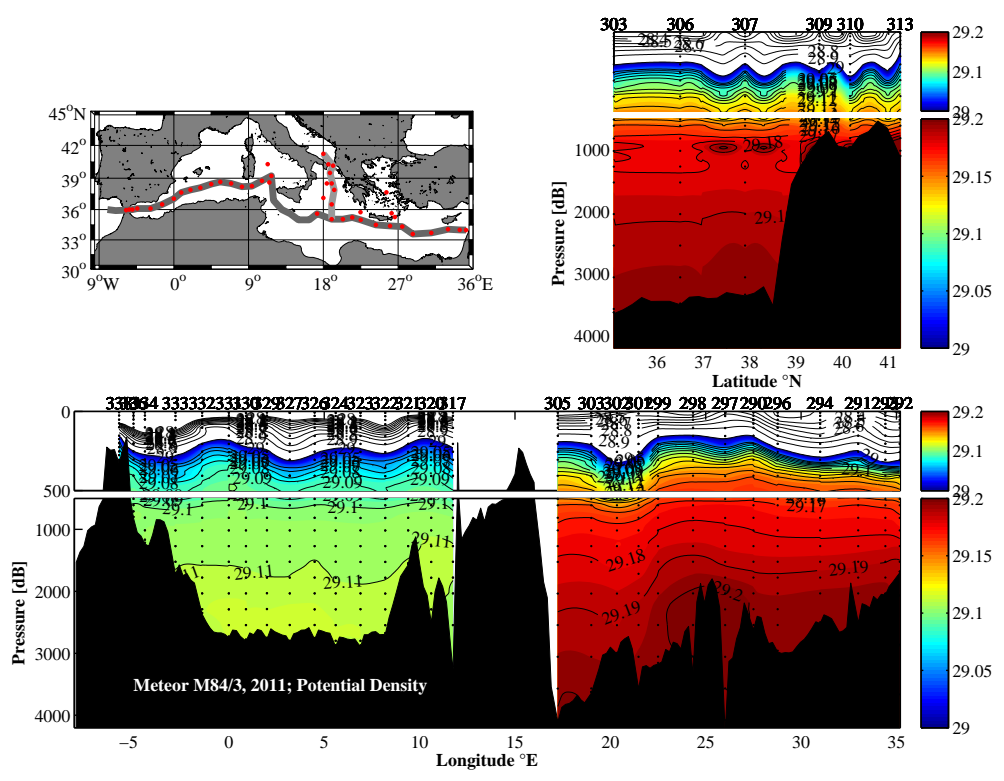

Fig. 5. Similar to Fig. 3, but for potential density $\left(\sigma_{\theta}\right)$. No stations are shown in the Atlantic due to the very different densities encountered there as compared to the Mediterranean Sea.

ranean Sea. Adriatic Deep Water (AdDW) is formed in the Southern Adriatic Pit (SAP) by means of open ocean convection and over the north and central Adriatic Sea continental shelves (e.g. Ovchinnikov et al., 1985; Bignami et al., 1990; Lascaratos et al., 1999). Water from the two formation regions within the Adriatic are transported southward and mixes along the Italian slope before exiting through the Otranto Strait (e.g. Cardin et al., 2011; Bensi et al., 2013). The newly formed deep water sinks to depth in the Ionian Sea forming the Eastern Mediterranean Deep Water (EMDW) (e.g. Hainbucher et al., 2006; Bensi et al., 2013). The water volume formed is highly variable depending on atmospheric and thermohaline conditions (Cardin et al., 2011). However, in the early 1990s the Aegean Sea became the main deep water formation area, generating an event known as the Eastern Mediterranean Transient (EMT). This event was first observed during the POEM-BC (Physical Oceanography of the eastern Mediterranean - Biology and Chemistry) program in the early 1990s (e.g. Robinson and Golnaraghi, 1994; Malanotte-Rizzoli et al., 1997, 1999), also reported on in a special issue of Deep-Sea Research II (Vol. 40, 1993). The EMT and its implications for the water mass properties and circulation have been described extensively in the literature (e.g. Roether et al., 1996, 2007; Klein et al., 1999, 2003; Lascaratos et al., 1999). The new deep water of Aegean origin (Cretan Deep Water - CDW) started to dominate the waters below $1200 \mathrm{~m}$ depth; it was characterized by higher temperature and salinity than previously when the deep water was dominated by water of Adriatic origin. Furthermore, the Eastern Mediterranean Deep Water of Aegean origin $\left(\mathrm{EMDW}_{\text {aegean }}\right)$ production rate during the years of stronger formation (1992 to the end of 1994) was distinctly higher
(2.8 Sv on average) (Roether et al., 2007) than the rate of that of Adriatic origin (0.3 Sv) (Roether and Schlitzer, 1991; Gačić et al., 1996; Astraldi et al., 1999). It is now suggested that the EMT was caused by the fact that very strong winters converged with the intrusion of high-salinity waters into the Aegean Sea (Josey, 2003; Gačić et al., 2013). The impact of the EMT on the climatology of the whole Mediterranean Sea was a matter of active research (e.g. Rohling and Bryden, 1992; Theocharis et al., 1999; Wu et al., 2000). More recently, the Adriatic has returned to be the principal Eastern Mediterranean Deep Water $\left(\mathrm{EMDW}_{\text {adriatic }}\right)$ source (Klein et al., 2000), although its salinity and temperature are now higher than the "classical" EMDW ${ }_{\text {adriatic }}$, and more similar to the deep water formed during the EMT (Rubino and Hainbucher, 2007; Cardin et al., 2011).

One potentially significant process for the preconditioning of the surface water prior to deep water formation in the eastern Mediterranean is the so-called Adriatic-Ionian Bimodal Oscillation System (BiOS) (Borzelli et al., 2009; Gačić et al., 2010) that can be described as follows: the alternating circulation regime of the NIG determines two different AW pathways in the Ionian, and consequently two opposite effects in the Ionian and in the Levantine basin. When the NIG is anti-cyclonic, the fresher AW flowing from the Sicily Channel meanders into the Northern Ionian, prolonging its pathway and consequently weakening its dilution effect when it mixes into the Levantine Basin. On the other hand, when the NIG is cyclonic, the main AW route is directly toward the Levantine Basin, exerting the maximum dilution effect in the Levantine Basin. Therefore, the salinity of the LIW formed in the Levantine Basin is higher when the NIG is anti-cyclonic and lower when the NIG is cyclonic (Gačić 
et al., 2013). This mechanism shows a decadal variability in the thermohaline characteristics of the LIW, and can explain the switches between Adriatic and Aegean as source regions for the EMDW. It has also been shown that nutrients' concentration in the northern Ionian and southern Adriatic are anti-correlated with salinity, and that the abundance of non-indigenous species of Atlantic origin increases during the anti-cyclonic phase of the NIG, whilst in the cyclonic phase, the occurrence of Levantine and Lessepsian species have been reported (Civitarese et al., 2010). It has been suggested that the BiOS mechanism could precondition the waters in the eastern Mediterranean so that events similar to the EMT could happen at regular intervals (Gačić et al., 2011, 2013), if the winter meteorological conditions in the Aegean Sea were severe enough to promote the massive dense water formation. However, the $\sim 100 \mathrm{yr}$ instrumental record does not show the occurrence of EMT-like events prior the 1980s (Roether et al., 2013b).

The renewal time of the deep water in the eastern Mediterranean is significantly longer then the corresponding ages in the western Mediterranean; about 100 and 20-40 yr, respectively (e.g. Roether et al., 1996; Stratford and Williams, 1997; Stratford et al., 1998). However, Stöven and Tanhua (forthcoming) finds higher mean-ages in the western as compared to the eastern Mediterranean Sea based on analysis of multiple tracer data. Transient tracer measurements suggest that the mean (or ideal) age of the deep eastern Mediterranean is $30-40 \mathrm{yr}$ in the deep Ionian Sea and about $80 \mathrm{yr}$ in the intermediate layer, for conditions prior to the EMT (Steinfeldt, 2004). However, Steinfeldt (2004) points out that these values are lower bounds, due to the limited integration time of the tracers used in the study. Based on CFC data collected in 2001, i.e. well after the EMT, Schneider et al. (2010) calculated mean ages of less than $60 \mathrm{yr}$ in the deep water, and $\sim 130 \mathrm{yr}$ in the intermediate "tracer minimum layer". Based on the knowledge of drastic changes both in the deep water formation rate and in the formation areas, temporal differences in ventilation of the deep eastern Mediterranean can be expected. Ventilation rates of the Mediterranean as found during 2011 is discussed by Stöven (2011) using multiple transient tracers.

\subsubsection{Western Mediterranean Sea}

In the western Mediterranean Basin, deep-water formation primarily takes place in the Gulf of Lions (e.g. Gascard, 1978; Killworth, 1983; Schott et al., 1993; Rhein, 1995; Tsimplis et al., 2006). During winter, dry and cold air mixes the AW and the Winter Intermediate Water (WIW) with the underlying, warmer and saltier LIW. Further heat loss leads to formation of Western Mediterranean Deep Water. The upper part of the deep water can pass the sill in the Sardinia Strait $(\sim 1900 \mathrm{~m})$ and enter the Tyrrhenian Sea. Here mixing with downwelling water from the eastern Mediterranean Sea seems to be an important mechanism in mixing the deep waters upward in the water column (Millot, 1999; Rhein et al., 1999; Vetrano et al., 2010). The Tyrrhenian Sea exports Tyrrhenian Deep Water to the western basin, a water mass that is characterized by relatively low transient tracer concentrations and is found between the WMDW and LIW (Rhein et al., 1999). Several studies have shown that the deep waters of the western Mediterranean have warmed and gained salinity during a large fraction of the instrumental record, i.e. at least since the mid-20th century (Béthoux et al., 1990; Rohling and Bryden, 1992; Krahmann and Schott, 1998). A study by Vargas-Yáñez et al. (2010) also suggests that the intermediate and surface waters of the western Mediterranean Sea is warming. The deep water formation is a transient event with time periods of more or less convective activity in the western Mediterranean Sea. An intense deep water renewal took place in the mid-2000s in the western Mediterranean, with a dramatic increase of $S$ and $T$ of the deep water, and the entire basin having been filled with new deep water within two years (e.g. Schroeder et al., 2008, 2010b).This event is known as the Western Mediterranean Transition (WMT). Gačić et al. (2013) has shown that about $60 \%$ of the salinity increase in the WMDW during the WMT can be explained by the decadal variability of salinity in the eastern Mediterranean in the context of the BiOS. This will likely have significant effects on biogeochemical properties in the western Mediterranean (e.g. Schroeder et al., 2008). In addition to deep waters, intermediate waters are formed during winter at the shelf/slope system in the northern part of the western Mediterranean Basin (Tsimplis et al., 2006) during years of less intense deep convection. The WIW follows the general circulation of the western basin underneath the AW.

\subsection{Oxygen in the Mediterranean Sea}

The oxygen distribution in the Mediterranean Sea is depicted in Fig. 6. The Mediterranean Sea is well oxygenated, and even the oxygen minimum layer (OML) at intermediate depths has oxygen concentrations in the order of $180 \mu \mathrm{mol} \mathrm{kg}^{-1}$ (the apparent oxygen utilization rate, $\mathrm{AOU}$ is $70-80 \mu \mathrm{mol} \mathrm{kg}^{-1}$ ). This is primarily related to the active and fast ventilation of the Mediterranean Sea (e.g. Roether and Schlitzer, 1991; Schneider et al., 2010; Stöven, 2011). Due to the low production in the oligotrophic Mediterranean waters, one would also expect low oxygen utilization rates (OUR), favoring high oxygen concentrations. However Roether and Well (2001) found OUR values similar to other ocean areas in the upper water column (calculated as a function of depth), and significantly higher OUR values in the deep layers $\left(0.53 \pm 0.19 \mu \mathrm{mol} \mathrm{kg}^{-1} \mathrm{a}^{-1}\right)$, and speculate that the high temperatures in the deep water could contribute to the high rates. Klein et al. (2003) found that the recently formed deep waters during the EMT contained labile dissolved organic carbon, brought from the surface layer to depth by convection, which enhanced the oxygen consumption rate to be $1.3 \mu \mathrm{mol} \mathrm{kg}-1 \mathrm{a}^{-1}$ and higher, i.e. more than twice 

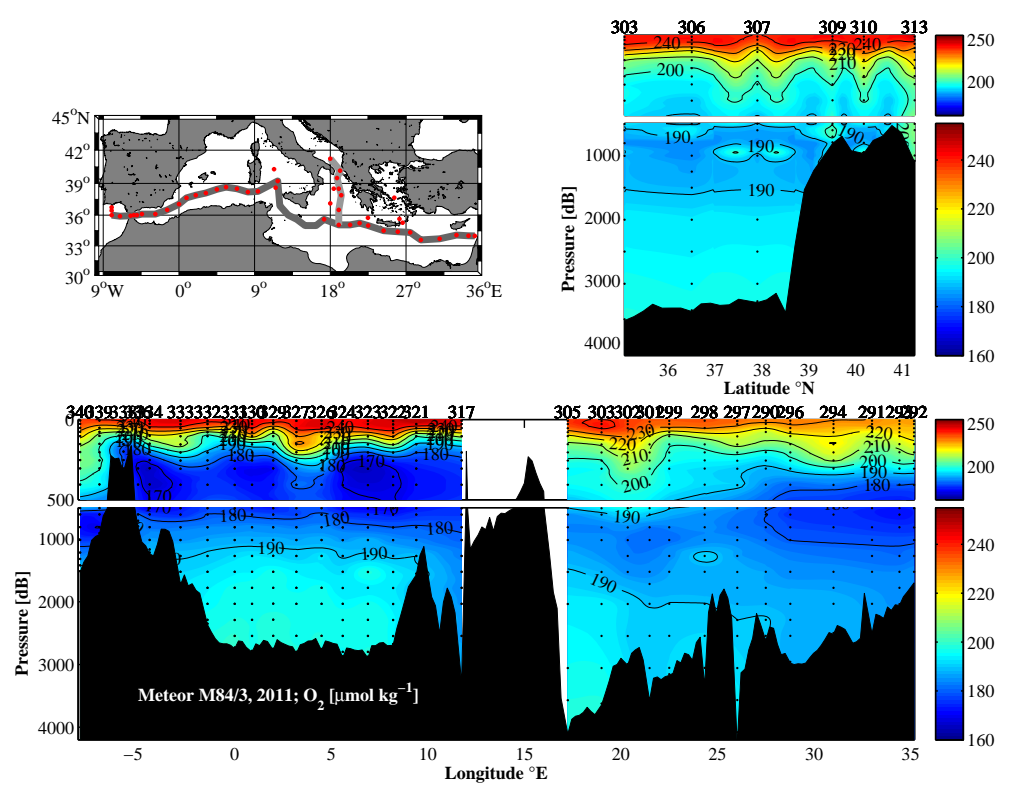

Fig. 6. Similar to Fig. 3, but for oxygen as determined from Winkler titration.

the values reported by Roether and Well (2001) for the conditions prior to the EMT. During a survey in the western Mediterranean Sea in the spring of 2005, oxygen levels above $210 \mu \mathrm{mol} \mathrm{kg}^{-1}$ were found in the deep waters and attributed to recently formed deep waters (Schroeder et al., 2006), which are higher than conditions before the WMT. Such high oxygen concentrations were not found during the 2011 Meteor survey, perhaps in analogy to the rapidly decreasing oxygen concentrations found in the deep water of the eastern Mediterranean Sea after an initial increase of oxygen due to invasion of recently ventilated surface waters to the deep waters (Klein et al., 2003).

The two sub-basins show significant differences in the distribution of dissolved oxygen. Although both sub-basins exhibit an OML, its vertical positions are different. In the eastern basin, the OML core lies in the depth range of 500$700 \mathrm{~m}$, well below the layer of maximum $S$ occupied by the LIW, whilst in the western basin the OML coincides with the LIW, with the core in the range of $300-400 \mathrm{~m}$ depth. Also the oxygen concentrations in the OML are different, and are lower in the western basin than in the eastern basin (also the AOU is higher in the western basin, not shown). This difference is mirrored by the nutrient maximum layer (NML) for the two basins. The OML is the result of two contrasting processes in the water column: the oxygen consumption due to the mineralization of the organic matter produced at surface, and the supply of oxygen by vertical and lateral diffusion and advection processes. In the case of the Mediterranean Sea there is a significant additional contribution of upward motion due to deep water formation processes (e.g. Klein et al., 2003). The balance of these processes sets the position and the oxygen concentration of the OML. It is worth con- sidering that the stratification below $250 \mathrm{~m}$ depth is higher in the eastern than in the western Mediterranean Sea, restricting upward diffusive mixing in the eastern as compared to the western basin. The horizontal distribution of oxygen (and several other properties) is more uniform in the western compared to the eastern basin. One explanation of this difference is that the morphology of the eastern basin is more complex than that of the Algero-Procençal basin. These morphological features restrict the spread of new, dense and more oxygenated waters into the abyssal interior of the eastern basin. This suggests that the western basin-wide horizontal mixing is faster in comparison to the eastern basin. This is reflected by the significantly shorter residence times of the deep water in the western as compared to the eastern Mediterranean Sea. Also transient tracer concentrations are higher in the WMDW compared to the EMDW (e.g. Stöven, 2011). However, there are large spatial and temporal variabilities in the transient tracer concentrations, and thus the ventilation age.

\subsection{Nutrients in the Mediterranean Sea}

The nutrient distributions in the Mediterranean Sea as found during April of 2011 are shown in Fig. 7 for nitrate $\left(\mathrm{NO}_{3}\right)$, Fig. 8 for phosphate $\left(\mathrm{PO}_{4}\right)$, and Fig. 9 for silicate $(\mathrm{Si})$. The Mediterranean Sea is generally characterized by very low nutrient concentrations, in particular the Eastern Mediterranean (e.g. Kress et al., 2003). The surface layers are generally almost fully nutrient depleted so that the Mediterranean is an oligotrophic, or even ultra-oligotrophic basin (e.g. Pujo-Pay et al., 2011). In addition, the nutrient distributions show that in the eastern Mediterranean the nutrientdepleted surface layer is thicker and the NML is deeper than in the western Mediterranean. The increased oligotrophy to- 

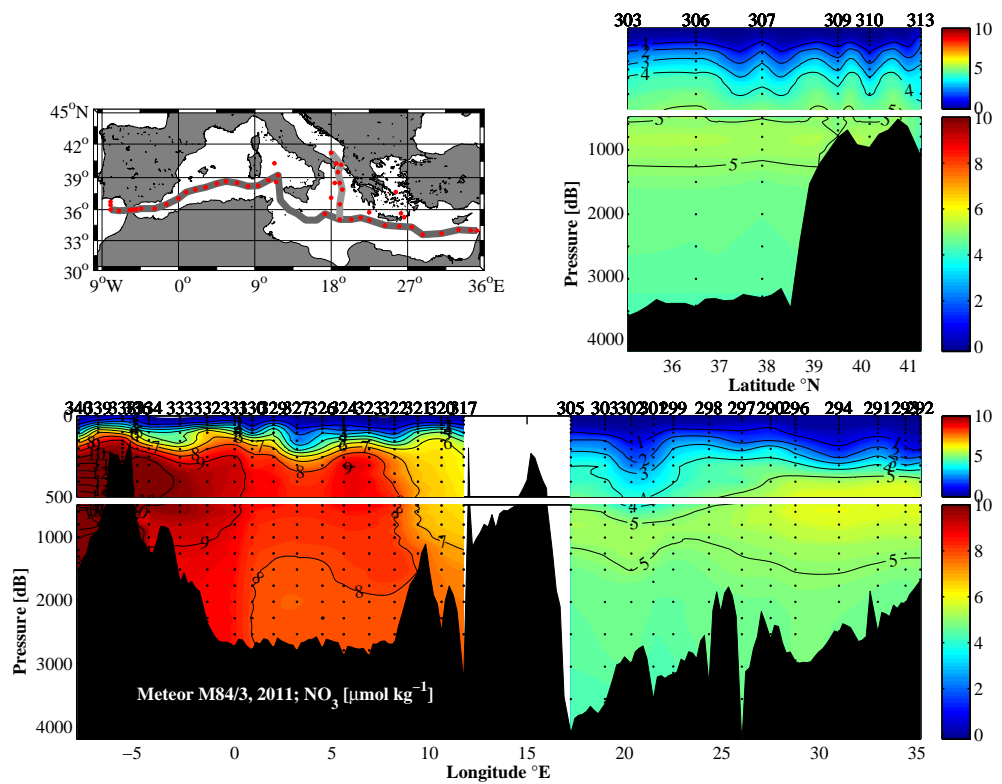

Fig. 7. Similar to Fig. 3, but for nitrate.
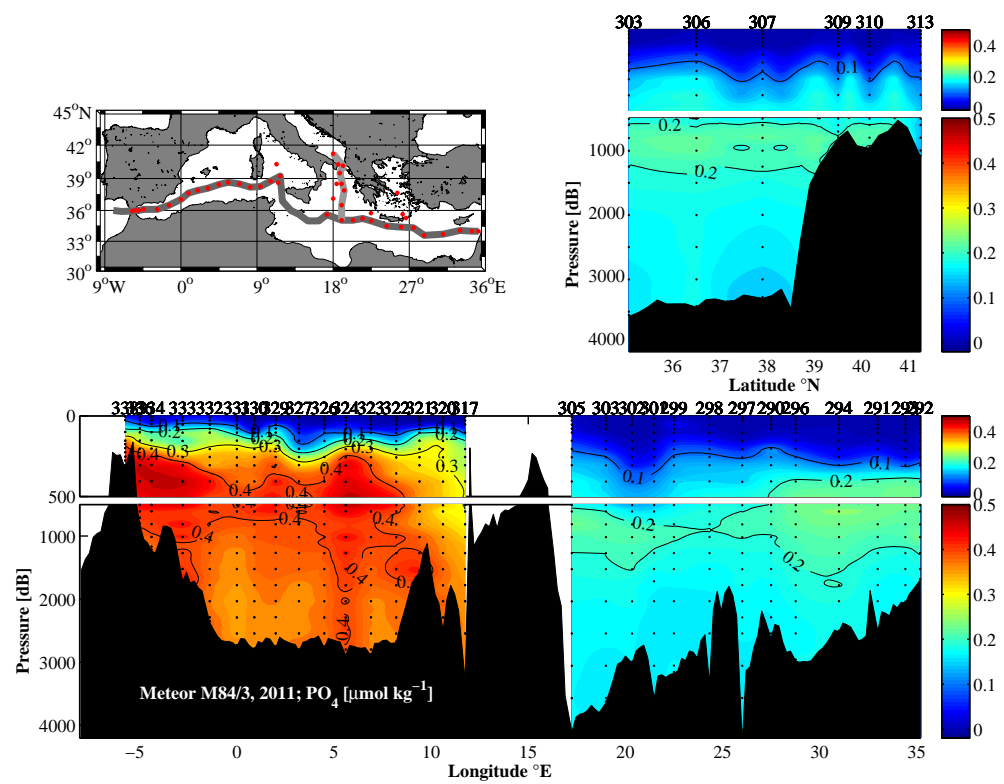

Fig. 8. Similar to Fig. 3, but for phosphate. No stations are shown in the Atlantic due to the very different phosphate values encountered there as compared to the Mediterranean Sea.

wards the east in the Mediterranean Sea is influenced by the higher intermediate and deep water stratification in the eastern Mediterranean Sea. A primary reason for low nutrient concentrations is the anti-estuarine circulation of the Mediterranean Sea, i.e. deep water with higher nutrient values is exported whereas low nutrient AW is imported (e.g. Huertas et al., 2012). However, an increasing trend for nitrate and phosphate concentrations in the deep water of the western Mediterranean has been observed, and attributed to anthropogenic perturbations (Béthoux et al., 1998, 2002).

Apart from the low concentrations, the interior of Mediterranean Sea is characterized by high $\mathrm{NO}_{3}: \mathrm{PO}_{4}$ (usually indicated as $\mathrm{N}: \mathrm{P}$ ) ratios; in the world ocean $\mathrm{N}: \mathrm{P}$ is classically determined to be around 16 (Redfield et al., 1963) whereas in the deep eastern basin the $\mathrm{N}: \mathrm{P}$ is $24-27$, and $20-22$ in the deep western basin. The debate on the origin of this peculiarity, often reported as anomaly, is still open. From 

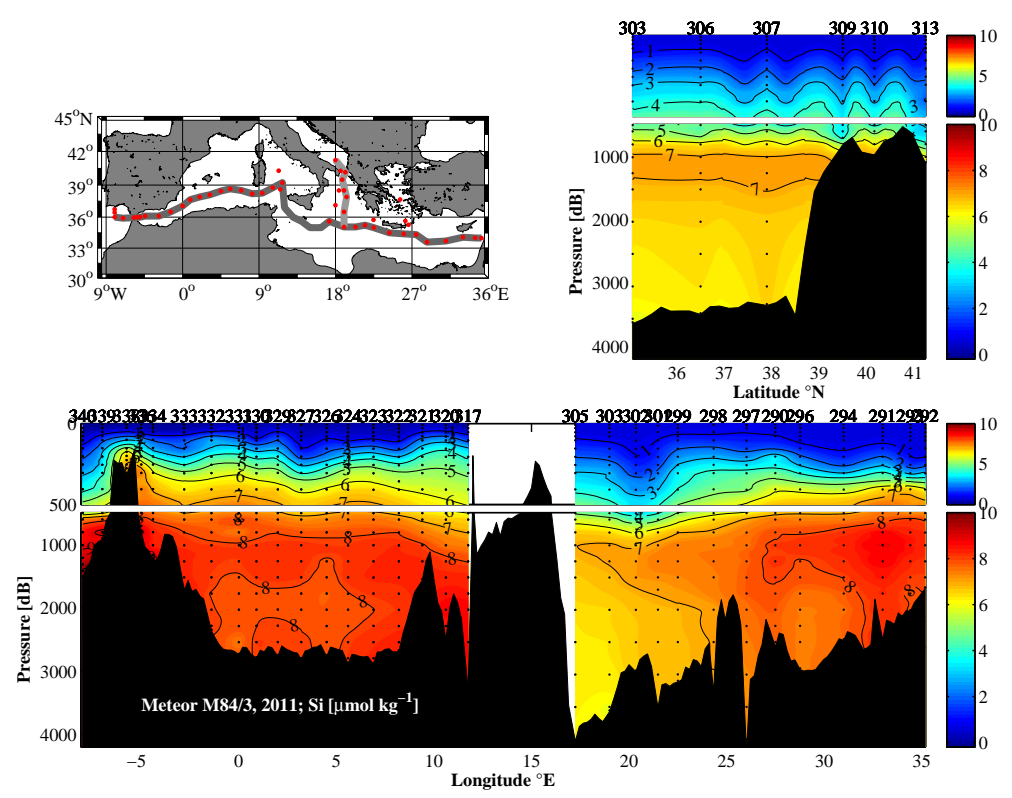

Fig. 9. Similar to Fig. 3, but for silicate.

the slight $\mathrm{N}$ : $\mathrm{P}$ increase usually observed in the deeper layer in the eastern Mediterranean, Civitarese et al. (1998) have proposed the Adriatic rivers as one of the possible sources of the N:P anomaly. Other authors suggested the remarkable unbalanced of $\mathrm{N}: \mathrm{P}$ ratio in the atmospheric inputs as another contribution to the general $\mathrm{N}: \mathrm{P}$ ratio anomaly in the Mediterranean. Also the lack of de-nitrification in the generally well oxygenated Mediterranean waters and sediments has been proposed as a source of the high $\mathrm{N}$ : P ratios (Krom et al., 2004, 2005). The Mediterranean, particularly the eastern basin, has been considered as phosphorus-limited for biological growth (Krom et al., 1991; Krom et al., 2004), although recent work suggests $\mathrm{N}$ or $\mathrm{N}$ and $\mathrm{P}$ co-limitations (e.g. Thingstad et al., 2005).

Nitrogen fixation rates in the Mediterranean Sea are generally low (e.g. Ibello et al., 2010; Bonnet et al., 2011), although higher rates were measured during the Meteor cruise during spring 2011 (Rahav et al., 2012). The concentrations of nitrate and phosphate in the deep layer are significantly higher in the western basin compared to the eastern basin (Figs. 7 and 8). Yet, the concentrations for silicate in the deep waters of both basins are similar (Fig. 9), although slightly lower in the Adriatic Sea, which influences the western part of the deep Ionian Sea. In a study of nutrient fluxes in the western Mediterranean Sea, Schroeder et al. (2010a) conclude that the eastern basin supplies nutrients to the western basin, which is one explanation for the higher nutrient concentrations in that basin. It is conceivable that the recent deep water formation events in the western Mediterranean Sea led to a decreased nutrient concentration in the deep water, as pointed out by Schroeder et al. (2010a). Observed temporal variability in nutrient and oxygen concen- trations must be put in context of observed variability in circulation and overturning.

Acknowledgements. The authors want to thank the captains and crews on the research vessels R/V Meteor, R/V Poseidon, and R/V Urania for the excellent cooperation during the campaigns. Thanks go to all scientists involved in the field campaigns for their enthusiastic work, and to all contributions for this special issue in Ocean Science. The Meteor cruise M84/3 was supported by a grant from the Deutsche Forschungsgemenschaft- Senatskommision für Ozenographie (DFG), and from a grant from the DFG; TA 317/3-1. The Poseidon cruise 414 was supported by funding from the University of Hamburg. The participation of V. Cardin and G. Civitarese was partly supported by the Mediterranean Science Commission (CIESM).

The service charges for this open access publication have been covered by a Research Centre of the Helmholtz Association.

Edited by: S. Sparnocchia

\section{References}

Álvarez, M., Sanleón-Bartolomé, H., Tanhua, T., Mintrop, L., Luchetta, A., Cantoni, C., Schroeder, K., and Civitarese, G.: The $\mathrm{CO}_{2}$ system in the Mediterranean Sea: a basin wide perspective, Ocean Sci. Discuss., 10, 1447-1504, doi:10.5194/osd-10-14472013, 2013.

Astraldi, M., Balopoulos, S., Candela, J., Font, J., Gacic, M., Gasparini, G. P., Manca, B., Theocharis, A., and Tintore, J.: The role of straits and channels in understanding the characteristics of Mediterranean circulation, Prog. Oceanogr., 44, 65-108, doi:10.1016/S0079-6611(99)00021-X, 1999. 
Baschek, B., Send, U., Lafuente, J. G., and Candela, J.: Transport estimates in the Strait of Gibraltar with a tidal inverse model, J. Geophys. Res., 106, 31033-31044, DOI:10.1029/2000jc000458, 2001.

Bensi, M., Rubino, A., Cardin, V., Hainbucher, D., and ManceroMosquera, I.: Structure and variability of the abyssal water masses in the Ionian Sea in the period 2003-2010, J. Geophys. Res. Oceans, 118, 931-943, doi:10.1029/2012JC008178, 2013.

Bergamasco, A. and Malanotte-Rizzoli, P.: The circulation of the Mediterranean Sea: a historical review of experimental investigations, Adv. Oceanogr. Limnol., 1, 11-28, doi:10.1080/19475721.2010.491656, 2010.

Béthoux, J. P., Gentili, B., Raunett, J., and Tailiez, D.: Warming trend in the western Mediterranean deep water, Nature, 347, 660$662,1990$.

Béthoux, J. P., Morin, P., Chaumery, C., Connan, O., Gentili, B., and Ruiz-Pino, D. P.: Nutrient in the Mediterranean Sea, mass balance and statistical analysis of concentrations with respect to environmental change, Mar. Chem., 63, 155-169, 1998.

Béthoux, J. P., Morin, P., and Ruiz-Pino, D. P.: Temporal trends in nutrient ratios: chemical evidence of Mediterranean ecosystem chages driven by human activity, Deep-Sea Res. II, 49, 20072016, 2002.

Bignami, F., Salusti, E., and Schiarini, S.: Observations on a bottom vein of dense water in the Southern Adriatic and Ionian Seas, J. Geophys. Res., 95, 7249-7259, 1990.

Bonnet, S., Grosso, O., and Moutin, T.: Planktonic dinitrogen fixation along a longitudinal gradient across the Mediterranean Sea during the stratified period (BOUM cruise), Biogeosciences, 8 , 2257-2267, doi:0.5194/bg-8-2257-2011, 2011.

Borzelli, G. L. E., Gačić, M., Cardin, V., and Civitarese, G.: Eastern Mediterranean Transient and reversal of the Ionian Sea circulation, Geophys. Res. Lett., 36, L15108, doi:10.1029/2009g1039261, 2009.

Bryden, H. L. and Kinder, T. H.: Steady two-layer exchange through the Strait of Gibraltar, Deep-Sea Res. Pt. A, 38, Supplement 1, S445-S463, doi:10.1016/s0198-0149(12)80020-3, 1991.

Bryden, H. L., Candela, J., and Kinder, T. H.: Exchange through the Strait of Gibraltar, Prog. Oceanogr., 33, 201-248, doi:10.1016/0079-6611(94)90028-0, 1994.

Cardin, V., Bensi, M., and Pacciaroni, M.: Variability of water mass properties in the last two decades in the South Adriatic Sea with emphasis on the period 2006-2009, Cont. Shelf. Res., 31, 951965, doi:10.1016/j.csr.2011.03.002, 2011.

CIESM: Designing Med-SHIP: a program for repeated oceanographic surveys, CIESM Workshop Monographs, edited by: Briand, F., CIESM, Monaco, 2012.

Civitarese, G., Gacic, M., Vetrano, A., Boldrin, A., Bregant, D., Rabitti, S., and Souvermezoglou, E.: Biogeochemical fluxes through the Strait of Otranto (eastern Mediterranean), Cont. Shelf. Res., 18, 773-789, 1998.

Civitarese, G., Gačić, M., Lipizer, M., and Eusebi Borzelli, G. L.: On the impact of the Bimodal Oscillating System (BiOS) on the biogeochemistry and biology of the Adriatic and Ionian Seas (Eastern Mediterranean), Biogeosciences, 7, 3987-3997, doi:10.5194/bg-7-3987-2010, 2010.

Gačić, M., Kovacevic, V., Manca, B. B., Papageorgiou, E., Poulain, P. M., Scarazzato, P., and Vetrano, A.: Thermohaline properties and circulation in the Strait of Otranto, in: Dynamic of Mediter- ranean straits and channels, edited by: Briand, F., 2, 117-145, 1996.

Gačić, M., Borzelli, G. L. E., Civitarese, G., Cardin, V., and Yari, S.: Can internal processes sustain reversals of the ocean upper circulation? The Ionian Sea example, Geophys. Res. Lett., 37, L09608, doi:10.1029/2010g1043216, 2010.

Gačić, M., Civitarese, G., Eusebi Borzelli, G. L., Kovacevic, V., Poulain, P. M., Theocharis, A., Menna, M., Catucci, A., and Zarokanellos, N.: On the relationship between the decadal oscillations of the northern Ionian Sea and the salinity distributions in the eastern Mediterranean, J. Geophys. Res., 116, C12002, doi:10.1029/2011jc007280, 2011.

Gačić, M., Schroeder, K., Civitarese, G., Cosoli, S., Vetrano, A., and Eusebi Borzelli, G. L.: On the relationship among the AdriaticIonian Bimodal Oscillating System (BiOS), the Eastern Mediterranean salinity variations and the Western Mediterranean thermohaline cell, Ocean Science, 9, 83-90, doi:10.5194/os-9-832013, 2013.

García-Lafuente, J., Sánchez-Román, A., Naranjo, C., and SánchezGarrido, J. C.: The very first transformation of the Mediterranean outflow in the Strait of Gibraltar, J. Geophys. Res., 116, C07010, doi:10.1029/2011jc006967, 2011.

Gascard, J. C.: Mediterranean deep water formation, baroclinic instability and oceanic eddies, Oceanol. Acta, 1, 315-330, 1978.

Hainbucher, D.: Cruise Report RV POSEIDON Cruise P414, http://www.geomar.de/fileadmin/content/zentrum/ze/fs/ Poseidon_Berichte_2011_PDF/POS414_Hainbucher.pdf, 2012.

Hainbucher, D., Rubino, A., and Klein, B.: Water mass characteristics in the deep layers of the western Ionian Basin observed during May 2003, Geophys. Res. Lett., 33, L05608, doi:10.1029/2005GL025318, 2006.

Huertas, I. E., Rios, A. F., Garcia-Lafuente, J., Navarro, G., Makaoui, A., Sanchez-Roman, A., Rodriguez-Galvez, S., Orbi, A., Ruiz, J., and Perez, F. F.: Atlantic forcing of the Mediterranean oligotrophy, Global Biogeochem. Cy., 26, Gb2022, doi:10.1029/2011 gb004167, 2012.

Ibello, V., Cantoni, C., Cozzi, S., and Civitarese, G.: First basin-wide experimental results on $\mathrm{N}-2$ fixation in the open Mediterranean Sea, Geophys. Res. Lett., 37, L03608, doi:10.1029/2009g1041635, 2010.

Josey, S. A.: Changes in the heat and freshwater forcing of the eastern Mediterranean and their influence on deep water formation, J. Geophys. Res., 108, 1-15, doi:10.1029/2003jc001778, 2003.

Kanarska, Y. and Maderich, V.: Modelling of seasonal exchange flows through the Dardanelles Strait, Estuarine, Coast. Shelf Sci. 79, 449-458, doi:10.1016/j.ecss.2008.04.019, 2008.

Kassis, D., Nittis, K., and Perivoliotis, L.: Hydrodynamic variability based on the multi-parametric POSEIDON Pylos observatory of the south Ionian Sea, Ocean Sci. Discuss., 10, 883-921, doi:10.5194/osd-10-883-2013, 2013.

Killworth, P. D.: Deep convection in the deep ocean, Rev. Geophys., 21, 1-26, 1983.

Klein, B., Roether, W., Manca, B. B., Bregant, D., Beitzel, V., Kovacevic, V., and Luchetta, A.: The large deep water transient in the Eastern Mediterranean, Deep-Sea Res. I, 46, 371-414, doi:10.1016/S0967-0637(98)00075-2, 1999.

Klein, B., Roether, W., Civitarese, G., Gacic, M., Manca, B. B., and d'Alcala, M. R.: Is the Adriatic returning to dominate the production of Eastern Mediterranean Deep Water?, Geophys. Res. 
Lett., 27, 3377-3380, doi:10.1029/2000g1011620, 2000.

Klein, B., Roether, W., Kress, N., Manca, B. B., d'Alcala, M. R., Souvermezoglou, E., Theocharis, A., Civitarese, G., and Luchetta, A.: Accelerated oxygen consumption in eastern Mediterranean deep waters following the recent changes in thermohaline circulation, J. Geophys. Res., 108, 8107, doi:10.1029/2002jc001454, 2003.

Krahmann, G. and Schott, F.: Longterm increases in Western Mediterranean salinities and temperatures: anthropogenic and climatic sources, Geophys. Res. Lett., 25, 4209-4212, 1998.

Kress, N., Manca, B. B., Klein, B., and Deponte, D.: Continuing influence of the changed thermohaline circulation in the eastern Mediterranean on the distribution of dissolved oxygen and nutrients: Physical and chemical characterization of the water masses, J. Geophys. Res., 108, 8109, doi:10.1029/2002JC001397, 2003.

Krom, M. D., Brenner, S., Kress, N., and Gordon, L. I.: Phosphorous limitation of primary prodauction in the Eastern Mediterranean Sea, Limnol. Oceanogr., 36, 424-443, 1991.

Krom, M. D., Herut, B., and Mantoura, R. F. C.: Nutrient budget for the Eastern Mediterranean: Implications for phosphorus limitation, Limnol. Oceanogr., 49, 1582-1592, 2004.

Krom, M. D., Woodward, E. M. S., Herut, B., Kress, N., Carbo, P., Mantoura, R. F. C., Spyres, G., Thingstad, T. F., Wassmann, P., Wexels-Riser, C., Kitidis, V., Law, C. S., and Zodiatis, G.: Nutrient cycling in the south east Levantine basin of the eastern Mediterranean: results from a phosphorus starved system, DeepSea Res. II, 52, 2879-2896, 2005.

Lascaratos, A., Roether, W., Nittis, K., and Klein, B.: Recent changes in deep water formation and spreading in the eastern Mediterranean Sea: a review, Prog. Oceanogr., 44, 5-36, doi:10.1016/s0079-6611(99)00019-1, 1999.

Malanotte-Rizzoli, P. and Hecht, A.: Large-Scale properties of the Eastern Mediterranean: A review, Oceanol. Acta, 11, 323-335, 1988.

Malanotte-Rizzoli, P., Manca, B. B., Ribera d'Alcala, M., Theocharis, A., Bergamasco, A., Bregant, D., Budillon, G., Civitarese, G., Georgopoulos, D., Michelato, A., Sansone, E., Scarazzato, P., and Souvermezoglou, E.: A synthesis of the Ionian Sea hydrography, circulation and water mass pathways during POEM-Phase I., Prog. Oceanogr., 39, 153-204, 1997.

Malanotte-Rizzoli, P., Manca, B., d'Alcala, R., Theocharis, A., Brenner, S., Budillon, G., and Özoy, E.: The Eastern Mediterranean in the 80 s and in the 90s: the big transition in the intermediate and deep circulations, Dynam. Atmos. Oceans, 29, 365395, 1999

Mapelli, F., Varela, M. M., Barbato, M., Alvariño, R., Fusi, M., Álvarez, M., Merlino, G., Daffonchio, D., and Borin, S.: Biogeography of planktonic microbial communities across the whole Mediterranean Sea, Ocean Sci. Discuss., 10, 291-319, doi:10.5194/osd-10-291-2013, 2013a.

Mapelli, F., Varela, M. M., Barbato, M., Alvariño, R., HernandoMorales, V., Fusi, M., Álvarez, M., Merlino, G., Daffonchio, D., Teira, E., and Borin, S.: Corrigendum to "Biogeography of planktonic bacterial communities across the whole Mediterranean Sea" published in Ocean Sci., 9, 585-595, 2013, Ocean Sci., 9, 681-681, doi:10.5194/os-9-681-2013, 2013 b.

Mariotti, A., Struglia, M. V., Zeng, N., and Lau, K. M.: The Hydrological Cycle in the Mediterranean Region and Implications for the Water Budget of the Mediter- ranean Sea, J. Climate, 15, 1674-1690, doi:10.1175/15200442(2002)015<1674:thcitm>2.0.co;2, 2002.

Millot, C.: Circulation in the Western Mediterranean Sea, J. Mar. Systems, 20, 423-442, 1999.

Millot, C. and Gerin, R.: The Mid-Mediterranean jet Artefact, Geophys. Res. Lett, 37, L12602, doi:10.1029/2010GL043359, 2010.

Millot, C. and Taupier-Letage, I.: Circulation in the Mediterranean Sea, in: The Mediterranean Sea, the Handbook of Environmental Chemistry, Springer, Berlin/Heidelberg, 29-66, 2005.

Moore, W. S.: The role of submarine groundwater discharge in coastal biogeochemistry, J. Geochem. Explorat., 88, 389-393, doi:10.1016/j.gexplo.2005.08.082, 2006a.

Moore, W. S.: Radium isotopes as tracers of submarine groundwater discharge in Sicily, Cont. Shelf. Res., 26, 852-861, doi:10.1016/j.csr.2005.12.004, 2006b.

Nielsen, J. N.: Hydrography of the Mediterranean and adjacent waters, in: Report of the Danish Oceanographic Expedition 19081910 to the Mediterranean and Adjacent Waters, Copenhagen, 72-191, 1912.

Ovchinnikov, I. M., Krivosheya, V. G., and Udodov, A. I.: Formation of deep eastern Mediterranean water in the Adriatic Sea, Oceanology, 25, 704-707, 1985.

Pujo-Pay, M., Conan, P., Oriol, L., Cornet-Barthaux, V., Falco, C., Ghiglione, J.-F., Goyet, C., Moutin, T., and Prieur, L.: Integrated survey of elemental stoichiometry $(\mathrm{C}, \mathrm{N}, \mathrm{P})$ from the western to eastern Mediterranean Sea, Biogeosciences, 8, 883-899, doi:10.5194/bg-8-883-2011, 2011.

Rahav, E., Herut, B., Levi, A., Mulholland, M. R., and BermanFrank, I.: Springtime contribution of dinitrogen fixation to primary production across the Mediterranean Sea, Ocean Sci., 9, 489-498, doi:10.5194/os-9-489-2013, 2013.

Redfield, A. C., Ketchum, B. H., and Richards, F. A.: The influence of organisms on the composition of seawater, in: The Sea, edited by: Hill, M. N., Wiley Interscience, New York, 1963.

Rhein, M.: Deep-Water Formation in the Western Mediterranean, J. Geophys. Res., 100, 6943-6959, 1995.

Rhein, M., Send, U., Klein, B., and Krahmann, G.: Interbasin deep water exchange in the western Mediterranean, J. Geophys. Res., 104, 23495-23508, 1999.

Robinson, A. and Golnaraghi, M.: The Physical and Dynamical Oceanography of the Mediterranean Sea, in: Ocean Processes in Climate Dynamics: Global and Mediterranean Examples, edited by: Malanotte-Rizzoli, P., and Robinson, A., NATO ASI Series, Springer, the Netherlands, 255-306, 1994.

Roether, W. and Lupton, J.: Tracers confirm downward mixing of Tyrrhenian Sea upper waters associated with the Eastern Mediterranean Transient, Ocean Science, 7, 91-99, doi:10.5194/os-7-91-2011, 2011.

Roether, W. and Schlitzer, R.: Eastern Mediterranean Deep-Water Renewal on the Basis of Chlorofluoromethane and Tritium Data, Dynam Atmos Oceans, 15, 333-354, doi:10.1016/03770265(91)90025-B, 1991.

Roether, W. and Well, R.: Oxygen consumption in the Eastern Mediterranean, Deep-Sea Research Part I, 48, 1535-1551, 2001

Roether, W., Manca, B. B., Klein, B., Bregant, D., Georgopoulos, D., Beitzel, V., Kovacevic, V., and Luchetta, A.: Recent changes in eastern Mediterranean deep waters, Science, 271, 333-335, 1996. 
Roether, W., Klein, B., Beitzel, V., and Manca, B. B.: Property distributions and transient-tracer ages in Levantine Intermediate Water in the Eastern Mediterranean, J. Mar. Systems, 18, 71-87, 1998.

Roether, W., Klein, B., Manca, B. B., Theocharis, A., and Kioroglou, S.: Transient Eastern Mediterranean deep waters in response to the massive dense-water output of the Aegean Sea in the 1990s, Prog. Oceanogr., 74, 540-571, 2007.

Roether, W., Jean-Baptiste, P., Fourré, E., and Sültenfuß, J.: The transient distributions of nuclear weapon-generated tritium and its decay product ${ }^{3} \mathrm{He}$ in the Mediterranean Sea, 1952-2011, and their oceanographic potential, Ocean Sci. Discuss., 10, 649-690, doi:10.5194/osd-10-649-2013, 2013a.

Roether, W., Klein, B., and Hainbucher, D.: The Eastern Mediterranean Transient: Evidence for Similar Events Previously?, in: The Mediterranean Sea: Temporal Variability and Spatial Patterns, edited by: Borzelli, G. L. E., Gacic, M., Malanotte-Rizzoli, P., and Lionello, P., AGU monographs, $2013 \mathrm{~b}$.

Rohling, E. J. and Bryden, H. L.: Man-Induced Salinity and Temperature Increases in Western Mediterranean Deep-Water, J. Geophys. Res., 97, 11191-11198, doi:10.1029/92jc00767, 1992.

Rubino, A. and Hainbucher, D.: A large abrupt change in the abyssal water masses of the eastern Mediterranean, Geophys. Res. Letters, 34, L23607, doi:10.1029/2007GL031737, 2007.

Schneider, A., Tanhua, T., Körtzinger, A., and Wallace, D. W. R.: High anthropogenic carbon content in the eastern Mediterranean, J. Geophys. Res., 115, C12050, doi:10.1029/2010JC006171, 2010.

Schneider, A., Tanhua, T., Roether, W., and Steinfeldt, R.: Changes in ventilation of the Mediterranean Sea during the past $25 \mathrm{yr}$, Ocean Sci. Discuss., 10, 1405-1445, doi:10.5194/osd-10-14052013, 2013.

Schott, F., Visbeck, M., and Send, U.: Open ocean deep convection, Mediterranean and Greenland Seas, in: Ocean Processes on Climate Dynamics: Global and Mediterranean Examples, edited by: Malanotte-Rizzoli, P., and Robinson, A. R., Kluwer Academic, Mass., 203-225, 1993.

Schroeder, K., Gasparini, G. P., Tanghelini, M., and Astraldi, M.: Deep and intermediate water in the western Mediterranean under the influence of the Eastern Mediterranean Transient, Geophys. Res. Lett., 33, L21607, doi:10.1029/2006GL027121, 2006.

Schroeder, K., Ribotti, A., Borghini, M., Sorgente, R., Perilli, A., and Gasparini, G. P.: An extensive western Mediterranean deep water renewal between 2004 and 2006, Geophys. Res. Lett., 35, L18605, doi:10.1029/2008GL035146, 2008.

Schroeder, K., Gasparini, G. P., Borghini, M., and Delfanti, R.: Biogeochemical tracers and fluxes in the Western Mediterranean Sea, spring 2005, J. Mar. Systems, 80, 8-24, 2010a.

Schroeder, K., Josey, S. A., Herrmann, M., Grignon, L., Gasparini, G. P., and Bryden, H. L.: Abrupt warming and salting of the Western Mediterranean Deep Water after 2005: Atmospheric forcings and lateral advection, J. Geophys. Res., 115, C08029, doi:10.1029/2009JC005749, 2010b.

Schroeder, K., Garcì-Lafuente, J., Josey, S. A., Artale, V., Buongiorno Nardelli, B., Carrillo, A., Gačić, M., Gasparini, G. P., Herrmann, M., Lionello, P., Ludwig, W., Millot, C., Özsoy, E., Pisacane, G., Sánchez-Garrido, J. C., Sannino, G., Santoleri, R., Somot, S., Struglia, M., Stanev, E., Taupier-Letage, I., Tsimplis, M. N., Vargas-Yáñez, M., Zervakis, V., and Zodiatis, G.: Chap- ter 3: Circulation of the Mediterranean Sea and its variability, in: The Climate of the Mediterranean Region, from the past to the future, edited by: Lionello, P., Elsevier Insights, Amsterdam, 2012.

Steinfeldt, R.: Ages and age spectra of Eastern Mediterranean Deep Water, J. Mar. Systems, 48, 67-81, doi:10.1016/j.jmarsys.2003.03.002, 2004.

Stöven, T.: Ventilation processes of the Mediterranean Sea based on CFC-12 ad SF6 measurements, Diploma, Leibniz-Institut für Meereswissenschaften der Mathematischnaturwissenschaftlichen Fakultät, Christian-Albrecht-Universität zu Kiel, Kiel, 2011.

Stratford, K. and Williams, R. G.: A tracer study of the formation, dispersal, and renewal of Levantine Intermediate Water, J. Geophys. Res., 102, 12539-12549, 1997.

Stratford, K., Williams, R. G., and Drakopoulos, P. G.: Estimating climatological age from a model-derived oxygen-age relationship in the Mediterranean, J. Mar. Systems, 18, 215-226, 1998.

Struglia, M. V., Mariotti, A., and Filograsso, A.: River Discharge into the Mediterranean Sea: Climatology and Aspects of the Observed Variability, J. Clim., 17, 4740-4751, doi:10.1175/jcli3225.1, 2004.

Tanhua, T., Hainbucher, D., Cardin, V., Álvarez, M., Civitarese, G., McNichol, A. P., and Key, R. M.: Repeat hydrography in the Mediterranean Sea, data from the Meteor cruise 84/3 in 2011, Earth Syst. Sci. Data, 5, 289-294, doi:10.5194/essd-5-289-2013, 2013.

Theocharis, A., Nittis, K., Kontoyiannis, K., Papageorgiou, E., and Balopoulos, E.: Climatic changes in the Aegean Sea influence the Eastern Mediterranean thermohaline circulation (1986-1997), Geophys. Res. Letters, 26, 1617-1620, doi:10.1029/1999g1900320, 1999.

Thingstad, T. F., Krom, M. D., Mantoura, R. F. C., Flaten, G. A., Groom, S., and Herut, B.: Nature of phosphorous limitation in the ultaoligotrophic Eastern Mediterranean, Science, 309, 10681071, 2005.

Tsimplis, M. N. and Bryden, H. L.: Estimation of the transports through the Strait of Gibraltar, Deep-Sea Res. Pt. I, 47, 2219 2242, doi:10.1016/s0967-0637(00)00024-8, 2000.

Tsimplis, M. N., Zervakis, V., Josey, S. A., Peneva, E. L., Struglia, M. V., Stanev, E. V., Theocharis, A., Lionello, P., MalanotteRizzoli, P., Artale, V., Tragou, E., and Oguz, T.: Changes in the Oceanography of the Mediterranean Sea and their Link to Climate Variability, in: Mediterranean Climate Variability, edited by: Lionello, P., Malanotte-Rizzoli, P., Boscolo, R., Elsevier publishing, 227-282, 2006.

Ulbrich, U., May, W., Li, L., Lionello, P., Pinto, J. G., and Somot, S.: The Mediterranean Climate Change under Global Warming, in: Mediterranean climate variability, edited by: Lionello, P., Malanotte-Rizzoli, P., and Boscolo, R., Elsevier, Amsterdam, 2006.

Ünlüata, Ü., Oguz, T., Latif, M. A., and Özoy, E.: On the physical oceanography of the Turkish Straits, in: The Physical Oceanography of Sea Straits, edited by: Pratt, L. J., NATO ASI Series Kluwer Academic Publishers, Dordrecht, The Netherlands, 2561, 1990.

Vargas-Yáñez, M., Moya, F., García-Martínez, M. C., Tel, E., Zunino, P., Plaza, F., Salat, J., Pascual, J., López-Jurado, J. L., and Serra, M.: Climate change in the Western Mediterranean Sea 
1900-2008, J. Mar. Systems, 82, 171-176, 2010.

Vetrano, A., Napolitano, E., Iacono, R., Schroeder, K., and Gasparini, G. P.: Tyrrhenian Sea circulation and water mass fluxes in spring 2004: Observations and model results, J. Geophys. Res., 115, C06023, doi:10.1029/2009jc005680, 2010.
Wu, P. L., Haines, K., and Pinardi, N.: Toward an understanding of deep-water renewal in the Eastern Mediterranean, J. Phys. Oceanogr., 30, 443-458, 2000.

Wüst, G.: On the Vertical Circulation of the Mediterranean Sea, J. Geophys. Res., 66, 3261-3271, 1961. 